\title{
Age differences in the urinary 17-ketosteroid response to environmental stress
}

WILLIAM P. PARÉ AND ANDREW LIVINGSTON, JR., VA HOSPITAL, Perry Point, Md. 21902

Urinary 17-ketosteroid (17-KS) measures were obtained from rats 50,100, 330 and 600 days old during a normal period and during a shock-stress period. No differences were observed between the age groups for the normal period, but 50- and 100-day-old Ss manifested significantly greater 17-KS values during the stress period as compared to the 330-and 600-day-old Ss.

As an organism grows older, its ability to make adjustments and to survive environmental stress is reduced considerably (Fabry \& Hruza, 1960; Grad \& Kral, 1957; Webb \& Agnew, 1962). In general this phenomenon reflects an imbalance between the anabolic and catabolic process in aging organisms. Numerous systems within the body show general decline and functional changes as a result of age. The adrenal cortex is one of these systems. Many investigators (Cope, 1964; Hamburger, Halvorsen, \& Pedersen, 1945; Johnsen, 1956; Kirk, 1949; Schraer, Schraer, Hartsfield, \& Gershon-Cohen, 1957) have documented the decrease, with age, of 17-ketosteroids (17-KS). This occurs both in the plasma and urine. The decrease in 17-KS reflects the reduced production of hormones by the adrenal cortex. The fact that older organisms do not adjust as readily to stress as do young adult organisms, may well be explained in part by the functional changes in the adrenal cortex occurring with age. Although the facts of reduced 17-KS output and reduced adaptive capability in older organisms have been recognized, these two phenomena have usually been considered independently and without reference to one another. The purpose of the present study was to determine if (1) the age-related decline in 17-KS output is also found in the rat, and (2) if rats of different ages manifest a similar urinary 17-KS response when exposed to shock stress.

Method. The Ss were 16 male Long Evans rats. These were separated into four age groups of four Ss each. At the beginning of the study the four Ss in each group were $50,100,330$, and 600 days old, respectively.

Each $\mathbf{S}$ was housed in an individual chamber. All chambers were identical. The chambers were grid boxes 7 in. wide, 8 in. deep, and 7 in. high. All walls were wood except the plastic front door. A 2 -in. hole was located in the chamber ceiling beyond which a small speaker was attached. A water cylinder was attached outside the plastic door, and the drinking spout protruded through the door into the chamber. A plastic food box was also attached outside the door. Via adjacent holes in the door and the food box, the $S$ could penetrate only his head into the food box in order to feed. The floor was composed of 3/16-in. brass rods spaced $3 / 2$ in. apart. Beneath the grid floor, a square funnel was suspended to collect urine. A fine wire screen between the cage floor and the funnel kept the funnel surface clean. A Model SS13 Scientific Prototype shock-source and scrambler was used to charge the chamber grids. A Model 377 Eico audio generator supplied the tone stimulus. A Gerbrands tape programmer controlled the onset of stimulus presentations.

All $16 \mathrm{Ss}$ were placed in their individual chambers for a habituation period of 10 days. The $\mathrm{Ss}$ had access to food and water throughout the whole study. After the habituation period, all Ss were weighed daily at 8:15 AM. Twenty-four hour urine samples were collected every third day at 8:30 AM. Urinary 17-KS determinations were carried out using a modification of the Zimmerman procedure reported by Drekter, Pearson, Bartczak, \& McGavack (1947). All Ss were left undisturbed for 17 days except for the daily routine of weighing and feeding. On Day 17 the stress schedule was introduced at 2:00 PM. This consisted of a $10 \mathrm{sec}$ tone followed by a 2-sec $1 \mathrm{~mA}$ scrambled shock via the grid floor. Tone-shock pairings were presented at random intervals with an average of $16 \mathrm{~min}$ intervening between presentations of tone-shock. The stress schedule was on for $6 \mathrm{~h}$, off for $6 \mathrm{~h}$, and on again for another $6 \mathrm{~h}$ terminating the morning of Day 18 . After two rest days, the same stress schedule was initiated on Day 20 and terminated on the morning of Day 21. Body weight was determined daily, and urinary 17-KS determi- nations were carried out on 24-h samples collected the mornings of Day 18 and Day 21.

Results and Discussion. The urinary 17-KS data for the different age groups are presented in Fig. 1. The data for the normal period, and the stress period were analyzed separately using Winer's (1962) two-factor analysis of variance design for repeated measures. The 17-KS values for the normal period did not reveal differences between the age groups. Unlike the human, the rat does not demonstrate a decline in $17-\mathrm{KS}$ as a function of age. This is true, however, only under basal conditions. Analysis of 17-KS values for the two stress-period determinations yielded significant differences between age groups $(\mathrm{F}=7.47, \mathrm{df}=3 / 12, \mathrm{p}$ $<.01)$. Further analysis indicated that groups scores for the 50 and 100-day-old Ss were significantly greater $(p<.01)$ than the group scores of the 330- and 600-day-old Ss. An inspection of Fig. 1 reveals these differences.

Mean body weight data are illustrated by Fig. 2 . Body weight was recorded every day as an attempt to ascertain the health of the Ss and also to observe the effects of the stress schedule. Many investigators (Brady, Thornton, \& DeFisher, 1962; Pare, 1965, Shapiro \& Melhado, 1958) have reported that loss in body weight represents a generalized response to environmental stress and suggest that body weight loss is a useful index for determining the deleterious effects of stress as experienced by experimental Ss. If this assumption is valid, the body weight data in Fig. 2 reveals that all four age groups were substantially affected by the stress schedule on Day 17 and Day 20. Whereas all four age groups responded with a similar body weight loss when exposed to stress, a definite age-related 17-KS response was observed. Younger Ss (50- and 100-day-old Ss) responded to the stress schedule with an increased 17-KS output, but old rats (330- and 600-day-old Ss) did not demonstrate a significant increase in 17-KS. These results support the observation reported by Verzár (1955) that following unilateral adrenalectomy, the resulting compenstory hypertrophy in the remaining gland was considerably less in the aged rat as compared to the young adult rat.

This differential response to stress of the adrenal cortex by young and old rats gives us some indication why the ability to cope with stress diminishes with age. Since the integrity of the pituitary-adrenocortical system is necessary for the body to handle emergency situations, a reduction in the functional operation of the adrenal cortex must have serious consequences. The reduced steroid secretion in aged organisms may explain in part why old Ss are less adaptive and more susceptible to diseases. Pincus (1960) has suggested that old Ss cannot survive long

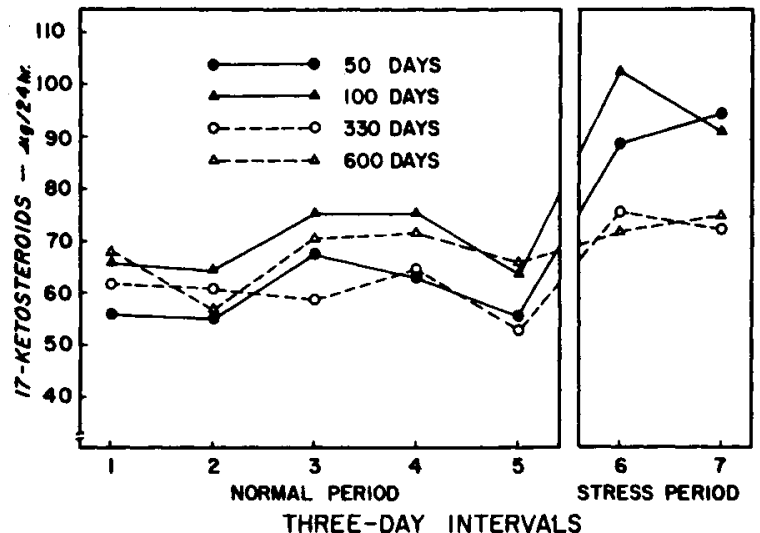

Fig. 1. Mean 17 ketosteroid values for the four age groups. 


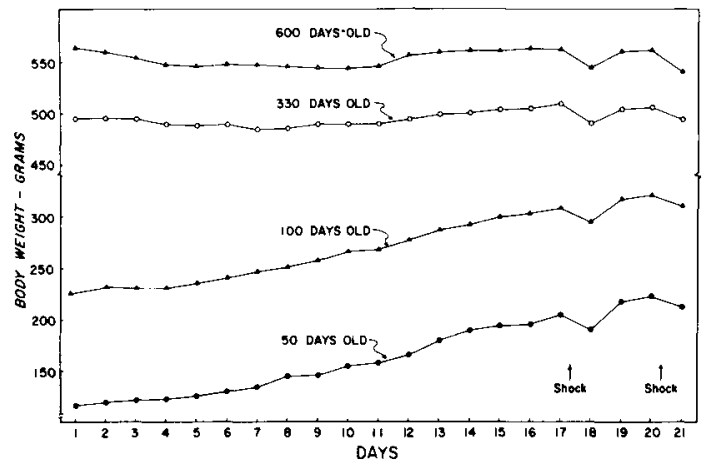

Fig. 2. Mean daily body weight for the four age groups for the entire experimental period. The words "shock" indicate when the stress schedule was introduced.

exposures to cold due to a reduced progesterone output. Since progesterone is thermogenic, this results in a diminished ability to maintain body temperature and jeopardizes the older organism in a cold environment. Aldosterone is another example. Its reduction results in a lack of ability to dispose of a water load. The present study demonstrated that older Ss respond to stress with an insufficient steroid output. As such their ability to cope with emergency situations is considerably reduced. This impairment may be the result of damage to the tissue of the adrenal cortex but it may also be due to an impairment of the processes responsible for ACTH production. Therefore, the relevant pathology may be located either in the adrenal cortex, or the anterior pituitary, or both.

\section{REFERENCES}

BRADY, J. P., THORNTON, D. R.. \& DeFISHER, D. Deleterious effects of anxiety elicited by conditioned pre-aversive stimuli in the rat. Psychosom. Med., 1962, 24, 590-595.

COPE, C. L. Adrenal steroids and diseases. Philadelphia: J. B. Lippincott, 1964.

DREKTER, I. J., Pearson, S., BARTCZAK, E., \& MCGAVACK, T. H. A rapid method for the determination of total urinary 17 -ketosteroids. J. clin. Fndocrinol., 1947, 7, 795-800.

FABRY, P., HRUZA, A. The effects of age on the ability of rats to adapt to mechanical trauma. Gerontologia, 1960, 4, 32-38.

GRAD, B., \& KRAL, V. A. The effects of senescence on resistance to stress. I. Response of young and old mice to cold. J. Geront., 1957, 12, 172-181.

HAMBURGER, C., HALVORSEN, K., \& PEDERSON, J. Assay of androgenic substances in the urine of normal men and women. Acta Pharmacol., 1945, 1, 129-140.

JOHNSEN, S. G. Fractionation of urinary 17-ketosteroids. Acta Endocrinol., 1956, 21, 146-156.

KIRK, E. The urinary excretion of neutral 17-ketosteroids in middle-aged and old men. J. Geront, 1949, 4, 34-38.

PARÉ, W. P. Stress and consummatory behavior in the albino rat. Psychol. Rep., 1965, 16, 399-405.

PINCUS, G. Steroid hormones and aging in man. In N. W. Shock (Ed.), Aging...Some social and biological aspects. Washington, D. C: Amer. Assoc. Adv. Sci., 1960. Pp. 189-197.

SCHRAER, H., SCHRAER, R., HARTSFIELD, M., \& GERSHON-COHEN, J. The urinary excretion of dehydroepiandrosterone and total 17-ketosteroids in aged men and women. J. Geront., 1957, 12, 391-393.

SHAPIRO, A. P., \& MELHADO, J. Observations on blood pressure and other physiologic and behavioral mechanisms in rats with behavioral disturbances Psychosom Med., 1958, 20, 303-313.

VERZÁR, F. Compensatory hypertrophy of kidney and adrenal in the lifespan of rats. In Old age in the modern world. Edinburgh: $\mathrm{E}$. \& S. Livingstone Ltd., 1955. Pp. 139-150.

WEBB, W. B., \& AGNEW, H. W. Sleep deprivation, age, and exhaustion in the rat. Science, 1962, 136, 1122.

WINER, B. J. Statistical principles in experimental design. New York: McGraw-Hill, 1962. 